\title{
The current status of Migrant Disaster Victim Identification in the Canary Islands
}

\author{
Caroline Wilkinson ${ }^{\circ}$ and Maria Castaneyra-Ruiz
}

Abstract: This migrant disaster victim identification report is based on an 18-month British Academy funded project, which focused on the Canary Islands, clarifying the state of play of documentation and connections with West Africa: primarily with Senegal, which is described as the main origin of the migrants to the Canary Islands. With the collaboration of Italian and Spanish academics and the utilisation of Canarian data, the report interrogates the challenges associated with the identification of migrant victims off the coast of the Canary Islands through fostered networks in the Canary Islands and Senegal. Finally, the report presents craniofacial depiction/analysis as an alternative biological and biometric tool for Migrant Disaster Victim Identification (MDVI). This project did not involve the implementation of migrant identification and this will hopefully be achieved through follow-up projects. The report ends with a summary of the current status and provides recommendations for future MDVI.

Keywords: migrant, disaster, victim, identification, Canary Islands, Senegal.

Notes on the authors: Professor Caroline Wilkinson is Director of Face Lab at Liverpool John Moores University and accredited by the Royal Anthropological Institute (RAI) as a Chartered Level I Forensic Anthropologist (craniofacial specialism).

Dr Maria Castaneyra-Ruiz is a Canarian Postdoctoral Researcher based in Face Lab at Liverpool John Moores University.

(C) The author(s) 2021. This is an open access article licensed under a

Creative Commons Attribution-NonCommercial-NoDerivs 4.0 Unported License 
The United Nations High Commissioner for Refugees (UNHCR) estimates that as many as 20,000 migrants have died making Mediterranean crossings in the last decade, and few migrants who perish at sea are ever positively identified. This represents a global humanitarian crisis.

Illegal immigration is currently a reality in many nations (Brian \& Laczko 2016) and economic migration is a critical issue for many European countries. Where migrants travel great distances, a large percentage reach the end of their lives attempting to cross bodies of water and inhospitable landmasses between origin and destination. Sometimes their bodies are found, but unfortunately, many are lost at sea, in deserts or in wasteland. Each unidentified migrant death leaves a family destined to uncertainty with potential administrative, legal and social repercussions, and the International Organization for Migration (IOM) states that in 2016, over 380,000 irregular migrants tried to enter Europe and more than 5,000 of these are missing or have died. ${ }^{1}$ Between 1 January and 17 February 2020 alone, 291 migrant deaths were recorded by IOM, national authorities and media sources.

However, although Europe woke up to the challenges of migrant deaths in 2013, it was 17 years earlier when the first boat arrived with irregular migrants to the Canary Islands. This pathway was one of the most utilised routes for the African migrants to reach Europe (Guillén 2011) and the most active years were 2000-6, when boats with greater capacity arrived and the migrant demographics diversified. More than 30,000 men, women and children arrived in the Canary Islands in 2006, with around 6,000 recorded deaths (Kemp 2016) and with many more suspected deaths. In one fishing village in Senegal with 40,000 inhabitants, it is said that everyone has lost someone, with as many as 1,500 young men who died/disappeared en route to Spain in 2006 (Andersson 2014). At the onset of this Canarian phenomenon, there was no process for how to deal with the migrant dead, and this new problem overwhelmed the islands. Some of these bodies were recorded (Last et al. 2016), but many migrants were buried without any information available for identification. Boats of migrants have continued to arrive ever since ( 23 boats carrying 708 migrants arrived in January 2020) ${ }^{2}$ and this has resulted in the creation of new institutions, ${ }^{3}$ laws $^{4}$ and border rules ${ }^{5}$ relating to the treatment of immigrants.

Current Disaster Victim Identification (DVI) databases (e.g. Interpol system) may not include the most appropriate information for migrant DVI (MDVI), as many of the usual methods of identification (DNA; fingerprints; dental) are often not available

\footnotetext{
${ }^{1} \mathrm{https} / / /$ missingmigrants.iom.int/

2 www.interior.gob.es/

${ }^{3}$ Casa Africa, www.casafrica.es/; OBITen, www.obiten.net/

${ }^{4}$ Plan Canario Inmigración 2002-2004; BOPC 2011.

${ }^{5}$ ORDEN PRE/3108/2006.
} 


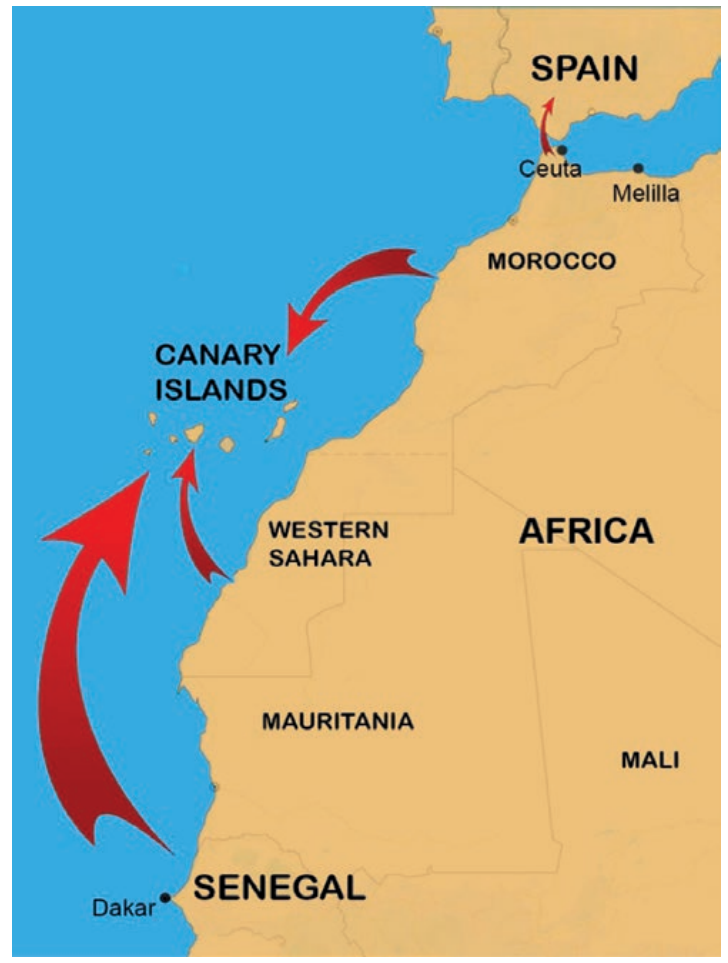

Figure 1. Map of illegal migrant routes from Africa to the Canary Islands.

due to the socioeconomic conditions of the countries of origin along with water damage and/or rapid decomposition. Delayed access to the migrant bodies may further confound these comparative methods. However, the contemporary rise of global networks and the use of mobile phone images has led to public acceptance of social media use in the search for missing people, and platforms, such as Facebook and Instagram, are frequently utilised to 'post' ante-mortem images of missing people (Laztza Nadeau 2017). This has created an opportunity for digital craniofacial analysis to be employed to match ante-mortem images to post-mortem images or depictions. Some European forensic databases have utilised 3D imaging for craniofacial analysis (Cattaneo et al. 2010; Brough et al. 2012), but these tend to be limited to national forensic casework rather than large-scale disaster scenarios. The 2018 IOM report states that the majority of deceased migrants are identified visually by family members and there are significant problems associated with visual recognition of the dead due to psychological/social pressures and post-mortem changes (Wilkinson \& Tillotson 2012). Craniofacial analysis is a valuable tool for forensic investigation and many individuals have been successfully identified as a direct result of a publicity campaign (Wilkinson 2010), but this technique has never been utilised in MDVI. 
Table 1. Migrant Disaster Victim Identification (MDVI) organisations in the Canary Islands.

Organisation in Canary MDVI process

Islands

Institutes of Medicolegal \& Autopsies and reports pass to the Guardia Civil

Forensic Science (IMLCF) Bodies sent to the cemeteries

Information applied by the Tribunal Superior de justiciar

The judge is responsible for the official identification-report with body register number and burial site

National DNA database for missing person (not criminal purposes). It is a blind database that cannot be consulted. It works just to search for matching

Charitable bodies take responsibility for the burials

Consulate of Senegal Store approx. 300 post-mortem photographs for migrants arrived at

Tenerife/Gran Canaria

Burials known-no more information

Thought to be Senegalese

International Committee

Red Cross (ICRC)

Update border death database (1994 until 2013)

ICRC data it is the most adapted for the identification of migrants

Centre International pour L'identification

Network of collaborators in Spain, Morocco, France, United Kingdom, Belgium, Switzerland

de Migrants Disparus

(CIPIMD)

Assist families to reclaim the bodies and identify through photography

Federation of African

Assist migrants who arrive to the islands

Associations in the Canary Assist people who reclaim a family member to raise money to repatriate Islands (FAA) the body

\section{Methodology}

This 18-month research project was funded by the British Academy and focused on the Canary Islands, clarifying the state of play of deceased migrant documentation and missing persons' connections with West Africa: primarily with Senegal, which is described as the main origin of migrants to the Canary Islands. This report is not commissioned nor politically aligned. Craniofacial anthropology researchers from Face Lab at the Liverpool John Moores University collaborated with identification experts from the Laboratory of Forensic Anthropology and Odontology (LABANOF) at the University of Milan and the Faculty of Medicine at the University La Laguna, Tenerife. The authors and collaborators are practising forensic anthropologists/academics with no formal links to any of the relevant identification groups, and the research focused on the Canary Islands, as one of the most popular routes from West African to Europe, with large numbers of unidentified migrant victims buried across the islands. 
Table 2. Numbers of migrant burials on the island of Fuerteventura by municipality and source as compared to the published data.

\begin{tabular}{llll}
\hline Fuerteventura migrant burials & & & \\
\hline Municipalities & www.borderdeaths.org & Niches counted & Difference \\
\hline La Oliva & 9 & 8 & -1 \\
Puerto del Rosario & 3 & 6 & +3 \\
Antigua & 32 & 37 & +5 \\
Tuineje & 60 & 23 & -37 \\
Pajara & 22 & 14 & -9 \\
Total & $\mathbf{1 2 6}$ & $\mathbf{8 8}$ & $\mathbf{- 3 8}$ \\
\hline
\end{tabular}

Data, narratives and information were collected through fostered networks in the Canary Islands (see tables 1 and 2) and Senegal (see table 3), during a nine-month research period in the Canary Islands and a one-month research visit to Senegal. In the Canary Islands, a review of the existing migrant data was performed using forensic anthropology records and information from sources such as the Guardia Civil, Red Cross, newspapers and courts archives (see table 2). In Senegal, the status of current West African missing people records was assessed through meetings/interviews with lay and community groups, identification agencies, police officers and government agencies and knowledge exchange sessions with key contacts. Finally, the information gathered from the Canary Islands and Senegal was assessed by all partners, in order to co-design practical standards for future international MDVI storage resources and MDVI policy (see table 4). A planned MDVI 2020 symposium in Liverpool with invited international experts was postponed due to the COVID-19 pandemic.

This resulting research report therefore interrogates the challenges associated with the identification of migrant victims in the Canary Islands, and evaluates the opportunities afforded by the worldwide use of social media and mobile phones to present craniofacial depiction/analysis as an alternative biological and biometric tool for MDVI. This project did not involve the implementation of migrant identification and this will hopefully be achieved through follow-up projects. The report ends with a summary of the current status and provides recommendations for future MDVI.

\section{Current practice}

The IOM and many identification experts are deeply troubled by the stark difference between the extensive efforts by European countries/organisations to systematically, efficiently and effectively identify victims of armed conflict or a humanitarian/ 
Table 3. Identification organisations based in Senegal with missing migrant data.

\begin{tabular}{|c|c|c|}
\hline Organisation & About & Missing migrant information \\
\hline $\begin{array}{l}\text { Réseau Migration } \\
\text { et le Développement } \\
\text { (REMIDEV) }\end{array}$ & $\begin{array}{l}2007 \text { government-supported network to bring } \\
\text { together NGOs and Senegalese associations } \\
\text { involved in migration } \\
\text { Concerned with the freedom of movement } \\
\text { and migrant rights }\end{array}$ & $\begin{array}{l}\text { Connection with IOM Dakar, but } \\
\text { do not collaborate as do not share } \\
\text { repatriation policies } \\
\text { Senegalese government collabo- } \\
\text { rates with activities of national } \\
\text { migration and immigrants in } \\
\text { Senegal, but not clandestine } \\
\text { migrants or missing migrants or } \\
\text { their families }\end{array}$ \\
\hline
\end{tabular}

Collective of Victims' Families of Clandestine Emigration (COFLEC) Created after the death of the founder's son in ACRFAT (Clandestine Returned a canoe heading to the Canary Islands in 2006 and Affected Families of Thiaroye Supported by number of Spanish NGOs Sur-mer) are associations from the same district in Dakar-recorded 374 deaths and 240 cases of people disappeared between 2006 and 2009
Diaspora
Development
Not-for-profit organisation to improve living ation Migration different stakeholders, in relation to migra- Senegal tion, mobilities, education and development (DIADEM Senegal) challenges

Data collected from 1,000 families in 35 regions of Senegal with lost migrant relatives to Canary Islands Importance of involvement with local religion and culture to promote the benefits to Senegalese communities

Emphasise the issues of the data protection law

Request death certificate to help children's education and family's heritage

Laboratory of Studies and GERM \& Faits de Sociétés is a research group The government does not take from Gaston Berger University in Saint-Louis, responsibility for clandestine
Research on Gender, Senegal. It is made up of research profesEnvironment, Religion \& sors, academics or researchers affiliated with national and international institutions

Migration (GERM)

Puente Humano

2004 project that made connections with students from Canary Islands and Senegal to raise awareness so that Senegalese youth do not consider clandestine migration

migration and victims - this is a taboo subject

There are associations linked with migration in all districts of Dakar, but there is not an officially recognised list Family liaison considered critical

At this moment, the population does not trust NGOs or international cooperation Louga is a migration village, many of the houses and business have been created with money from migrants

Hahatay Gandiol Raises awareness of the dangers of clandestine 2006 personal experience of trip migration from Dakar to La Gomera in a canoe (lasting eight days) 
Table 3. Continued

\begin{tabular}{|c|c|c|}
\hline Organisation & About & Missing migrant information \\
\hline ICRC Senegal & $\begin{array}{l}\text { International Committee Red Cross } \\
\text { in Senegal }\end{array}$ & $\begin{array}{l}\text { Created the project 'Trace the } \\
\text { Faces' where the families can try to } \\
\text { find their missing migrants } \\
\text { Do not collect data relating to } \\
\text { physical appearance } \\
\text { In Senegal, created a project for } \\
\text { psychological support for families } \\
\text { with missing migrants who are } \\
\text { suffering financial, legal or admin- } \\
\text { istrative difficulties } \\
\text { Creating national list of missing } \\
\text { persons }\end{array}$ \\
\hline $\begin{array}{l}\text { The International } \\
\text { Organization for } \\
\text { Migration (IOM) }\end{array}$ & Missing Migrants Project (MMP) & $\begin{array}{l}\text { Online MMP_includes realistic } \\
\text { database of missing migrants from } \\
\text { Senegal } \\
\text { More interested in the live move- } \\
\text { ment of people between Canary } \\
\text { Islands and Senegal than the iden- } \\
\text { tification of migrant victims }\end{array}$ \\
\hline
\end{tabular}

natural disaster, and how little effort is made to identify migrant disaster victims (Latza Nadeau 2017; Singleton et al. 2017). There appears to be a second-class system for processing migrant deaths. The IOM states that migrants' rights should be protected during the whole circle of migration (IOM 2013), and this is especially challenging where the individuals originate from low-income countries, where identification details are absent and migration is undocumented or unmonitored. The social, legal and religious implications of misidentification are manifest and the need to identify the dead and its importance for humanitarian, administrative, judicial and other purposes are universal values enshrined by domestic and international law, including the four Geneva Conventions of 1949 and their Additional Protocols of 1977. Some European countries have created a database to collect DNA and anthropological information prior to internment of migrant victims in order to facilitate future identification (Cattaneo et al. 2010; 2015). However, many other countries do not even try to collect information on the migrant dead and bodies are cremated or interred without any identification process. There is no central international database that connects the images, numbers and internment locations, and certainly no collection and cataloguing of biological profiles or identifying characteristics. The European Commissioner for Human Rights (2007) argued that it was imperative to begin a process to identify and account for the thousands of 'missing' undocumented migrants whose identities are unknown. However, despite the frequency and magnitude of these tragedies over 
Table 4. Recommended content for an online MDVI database.

\begin{tabular}{lllll}
\hline $\begin{array}{l}\text { Post }- \\
\text { mortem }\end{array}$ & Factor Details & Data & Storage format & $\begin{array}{l}\text { Application to } \\
\text { MDVI in the } \\
\end{array}$ \\
& & & Canary Islands
\end{tabular}

\begin{tabular}{|c|c|c|c|c|c|}
\hline \multirow[t]{5}{*}{$\begin{array}{l}\text { Migrant } \\
\text { Disaster } \\
\text { Victim }\end{array}$} & Case & $\begin{array}{l}\text { Body retrieval } \\
\text { report }\end{array}$ & $\begin{array}{l}\text { ID number } \\
\text { Date } \\
\text { Island municipality }\end{array}$ & $\begin{array}{l}\text { Coastguard/police } \\
\text { report } \\
\text { Interpol DVI form } \\
\text { (pink) }\end{array}$ & $\begin{array}{l}\text { Possible from } \\
\text { records or news } \\
\text { reports } \\
+ \text { burial location }\end{array}$ \\
\hline & Disaster & Type of disaster & $\begin{array}{l}\text { Number of } \\
\text { casualties } \\
\text { Origin of migrants } \\
\text { Condition of } \\
\text { bodies }\end{array}$ & $\begin{array}{l}\text { Coastguard/police } \\
\text { report } \\
\text { Interpol DVI form } \\
\text { (pink) } \\
\text { Scene photographs }\end{array}$ & $\begin{array}{l}\text { Possible from } \\
\text { records or news } \\
\text { reports }\end{array}$ \\
\hline & $\begin{array}{l}\text { Biological } \\
\text { profile }\end{array}$ & $\begin{array}{l}\text { Sex } \\
\text { Gender } \\
\text { Age } \\
\text { Population } \\
\text { Height } \\
\text { BMI }\end{array}$ & $\begin{array}{l}\text { Descriptions } \\
\text { Measurements }\end{array}$ & $\begin{array}{l}\text { Pathology or anthro- } \\
\text { pology report } \\
\text { Interpol DVI form } \\
\text { (pink) }\end{array}$ & $\begin{array}{l}\text { Osteology } \\
\text { report possible } \\
\text { from skeleton }\end{array}$ \\
\hline & $\begin{array}{l}\text { Clothing } \\
\text { Belongings }\end{array}$ & $\begin{array}{l}\text { Type } \\
\text { Colour } \\
\text { Size } \\
\text { Features } \\
\text { Damage }\end{array}$ & $\begin{array}{l}\text { Descriptions } \\
\text { Photographs }\end{array}$ & $\begin{array}{l}\text { Coastguard/police } \\
\text { report } \\
\text { Interpol DVI form } \\
\text { (pink) } \\
\text { Image gallery } \\
\text { Exhibits }\end{array}$ & No \\
\hline & $\begin{array}{l}\text { Physical } \\
\text { indicators }\end{array}$ & $\begin{array}{l}\text { Tattoos } \\
\text { Moles/marks } \\
\text { Scars } \\
\text { Implants } \\
\text { Modifications } \\
\text { Medical } \\
\text { Hair } \\
\text { Skin } \\
\text { Eyes } \\
\text { Trauma } \\
\text { Prostheses }\end{array}$ & $\begin{array}{l}\text { Descriptions } \\
\text { Photographs } \\
\text { CT scans } \\
\text { Laser scans }\end{array}$ & $\begin{array}{l}\text { Interpol DVI form } \\
\text { (pink) } \\
\text { Image gallery } \\
\text { File and image } \\
\text { gallery } \\
\text { File and image gallery } \\
\text { Pathology or anthro- } \\
\text { pology report }\end{array}$ & $\begin{array}{l}\text { No } \\
\text { osteology report } \\
\text { possible from } \\
\text { skeleton }\end{array}$ \\
\hline
\end{tabular}

\begin{tabular}{|c|c|c|c|c|}
\hline $\begin{array}{l}\text { Facial } \\
\text { indicators }\end{array}$ & $\begin{array}{l}\text { Feature } \\
\text { appearance } \\
\text { Hair } \\
\text { Eyes } \\
\text { Scars } \\
\text { Moles/marks } \\
\text { Modifications } \\
\text { Dental }\end{array}$ & $\begin{array}{l}\text { Descriptions } \\
\text { Photographs } \\
\text { CT scans } \\
\text { Laser scans }\end{array}$ & $\begin{array}{l}\text { Interpol DVI form } \\
\text { (pink) } \\
\text { Image gallery } \\
\text { File and image gallery } \\
\text { File and image gallery } \\
\text { Craniofacial report }\end{array}$ & $\begin{array}{l}\text { Possible photos } \\
\text { Possible cranio- } \\
\text { facial analysis } \\
\text { from skeleton }\end{array}$ \\
\hline $\begin{array}{l}\text { Biological } \\
\text { indicators }\end{array}$ & $\begin{array}{l}\text { DNA } \\
\text { Fingerprints } \\
\text { Odontology/ } \\
\text { dental }\end{array}$ & $\begin{array}{l}\text { Samples } \\
\text { Set of prints } \\
\text { Records and } \\
\text { radiographs }\end{array}$ & $\begin{array}{l}\text { Interpol DVI form } \\
\text { (pink) } \\
\text { Image gallery } \\
\text { File } \\
\text { Odontology report }\end{array}$ & $\begin{array}{l}\text { Possible DNA } \\
\text { Possible } \\
\text { odontology } \\
\text { report from } \\
\text { skeleton }\end{array}$ \\
\hline
\end{tabular}


Table 4. Continued

\begin{tabular}{|c|c|c|c|c|c|}
\hline $\begin{array}{l}\text { Ante- } \\
\text { mortem }\end{array}$ & Factor & Details & Data collection & Storage format & $\begin{array}{l}\text { Missing } \\
\text { migrants }\end{array}$ \\
\hline \multirow[t]{8}{*}{ Migrant } & Identity & Name & ID documents & $\begin{array}{l}\text { File } \\
\text { Image gallery }\end{array}$ & Family \\
\hline & Migration & $\begin{array}{l}\text { Date } \\
\text { Boat } \\
\text { Passengers } \\
\text { Route } \\
\text { Organisation }\end{array}$ & Descriptions & $\begin{array}{l}\text { Text } \\
\text { Map }\end{array}$ & Family \\
\hline & Biological profile & $\begin{array}{l}\text { Sex } \\
\text { Gender presentation } \\
\text { Age } \\
\text { Population }\end{array}$ & $\begin{array}{l}\text { Descriptions } \\
\text { Photographs }\end{array}$ & $\begin{array}{l}\text { Interpol DVI } \\
\text { form (yellow) } \\
\text { Image gallery }\end{array}$ & Family \\
\hline & $\begin{array}{l}\text { Clothing } \\
\text { Belongings }\end{array}$ & Identifying features & $\begin{array}{l}\text { Descriptions } \\
\text { Photographs }\end{array}$ & $\begin{array}{l}\text { Interpol DVI } \\
\text { form (yellow) } \\
\text { Image gallery }\end{array}$ & $\begin{array}{l}\text { Family } \\
\text { Social media }\end{array}$ \\
\hline & Physical indicators & $\begin{array}{l}\text { s Identifying features } \\
\text { Medical } \\
\text { Dental }\end{array}$ & $\begin{array}{l}\text { Descriptions } \\
\text { Clinical imaging } \\
\text { Records } \\
\text { Photographs }\end{array}$ & $\begin{array}{l}\text { Interpol DVI } \\
\text { form (yellow) } \\
\text { Image gallery } \\
\text { File }\end{array}$ & $\begin{array}{l}\text { Family } \\
\text { GP } \\
\text { Dentist } \\
\text { Social media }\end{array}$ \\
\hline & Facial indicators & Identifying features & $\begin{array}{l}\text { Descriptions } \\
\text { Photographs }\end{array}$ & $\begin{array}{l}\text { Interpol DVI } \\
\text { form (yellow) } \\
\text { Image gallery } \\
\text { File }\end{array}$ & $\begin{array}{l}\text { Family } \\
\text { Social media }\end{array}$ \\
\hline & Biological samples & $\begin{array}{l}\text { DNA } \\
\text { Fingerprints }\end{array}$ & $\begin{array}{l}\text { Migrant } \\
\text { belongings } \\
\text { Family members }\end{array}$ & & Family \\
\hline & Mobile phone & Social media & Archival material & $\begin{array}{l}\text { Text } \\
\text { Links }\end{array}$ & Family \\
\hline
\end{tabular}

the last ten years, European governments have been slow to recognise that families have a right to know the fate of missing migrant relatives (Ben Attia 2016). It is worth noting that communication with relatives of the missing may create danger for the family and family members may be reluctant to speak to the authorities due to fears of criminal investigation, extensive funerary costs or social exclusion. Only 22 per cent of deceased migrants are ever identified (IOM 2018).

The International Organization for Migration (IOM) Missing Migrants Project is widely acknowledged as the leading authority on border deaths (Ampuero Villagran 2018; Cuttitta 2020) and included the first systematic compilation of data on "migrants who have died or gone missing at the external borders of states, or in the process of migration towards an international destination' (Batalova 2018). The MMP collects information of the migrants' age, gender, origin, location, and cause of death, 
primarily sourced from IOM and government reporting along with NGO and media accounts, in order to create a globally accessible database. However, there are recognised, inherent difficulties to maritime migrant disaster victim identification, and these include:

1. Difficulty in determination of migrant origin - many do not carry identity documents/passports, or these may be lost/destroyed during the disaster (Ampuero Villagran 2018).

2. Migrant deaths may be actively covered up or left unreported if smugglers or traffickers are involved (Triandafyllidou and McAuliffe 2018).

3. Water-based decomposition, tidal movement and/or animal activity can lead to loss of clothing/belongings, physical features and facial appearance (Ellingham 2017).

Experts (Kovras \& Robins 2016) state that identification is also hindered by the current lack of European nation legal provisions and international agreements resulting in ad hoc practices with poor funding, overlapping mandates, and unsystematic collection and storage of information. The 2018 Mediterranean Migrant Policy Report (05/02) by the United Nations University Institute on Globalisation, Culture and Mobility (UCUI-GCM) states that the management of dead migrant bodies is often categorised into five stages that include retrieval, transportation, autopsy, storage and burial/repatriation; with identification information collected, collated and evaluated at each stage (Ben Attia et al. 2017). As stated in the UNUI-GCM report (Ampuero Villagran 2018), the initial procedure at Mediterraean migrant disasters includes photographic recording of the body (taken by coast guards, police officers or forensic experts) and the attachment of a MDVI code that includes migrant gender and date of retrieval. Although coroners will usually examine the bodies and collect primary characteristics to report to the national authorities, full post-mortem examinations will only be requested if there are concerns related to the cause of death. Finally, the migrant disaster victims are transported to be buried in anonymous local graves; in the Canary Islands these are above-ground, sealed spaces/drawers in a wall to hold human remains, known as niches/crypts. Since identification is essentially the reconciliation of post-mortem (PM) data from the unknown body with corresponding ante-mortem (AM) data from registries or families of the missing, the practices currently in place for the management and identification of migrant bodies in the Mediterranean are largely inadequate (GMDAC 2016). In the aftermath of a disaster, critical evidence that migrants carry with them, including mobile phones, are often neglected. Much of the useful identification data stored on mobile phones can be accessed in social media or iCloud storage, but this data is never collected as it would involve interviews with families in the country of origin. 


\section{The Canary Islands}

The Canary Islands are seven islands belonging to Spain located in the Atlantic Ocean close to the North African coast; the closest island (Fuerteventura) is $100 \mathrm{~km}$ from the port of Tarfaya in Morocco (see figure 1). These islands provide an illegal entrance into Europe from Africa through a maritime migration route that became popular from 1995 due to a particular set of political and geographic circumstances. Firstly, Spain joined the European Union in 1986, whereupon the Spanish cities of Ceuta and Melilla, that sit on the northern shores of Morocco's Mediterranean coast, became the European Union's only land entry points from Africa and their borders came under pressure from African migrants seeking a better life in Europe (see figure 1). Both port cities developed as military and trade centres linking Africa to Europe and have had limited self-government as autonomous communities since 1995. Enhanced security (perimeter fences, infrared cameras) was installed at their borders in 1995, due to pressure from EU member countries, forcing African migrants to consider alternative routes into Europe. Fall (2007) claims that illegal migration from sub-Saharan Africa to Europe and more specifically to the Canary Islands is probably linked to the enforcement of the border controls in the Spanish enclaves and transition countries (Mbaye 2014: Maher 2015). Secondly, after 2000, the border controls at the Straits of Gibraltar were intensified and this also forced illegal migrants to use boats to reach European coasts such as Lampedusa, Sicily or the Canary Islands (Adepoju 2008; De Haas 2006).

The first arrivals to the Canary Islands came via Morocco on small boats in the early years of the 1990s. These 'pateras' came mostly to the eastern islands and their success established the direct migration route (Rodríguez Díaz \& Montes 2008). This route was used almost daily until the later years of the 1990s, when international agreements managed some control. The migrant origin then relocated to the more southern West African countries, making the routes longer and more dangerous. Many of these people were originally from Senegal, and the motto of thousands of Senegalese who tried to migrate illegally was 'Barsa wala Barsakh', which in Wolof means 'Barcelona or Die'. The small boats used also transitioned to the traditional Senegalese fishing canoes (cayucos), which had greater capacity accommodating more than 100 people. To understand the scope of this phenomenon, half of the 30,000 illegal migrants who arrived in the Canary Islands in 2006 (the peak) were Senegalese (Dudek \& Pestano 2019), while 1,000 out of 7,000 African illegal migrants who died during the crossings in the same year were Senegalese. ${ }^{6}$

It has not been a priority for the Spanish or Canarian authorities to identify deceased migrants. For this reason, there is a paucity of data and no specific protocols

\footnotetext{
${ }^{6}$ Asociación Pro Derechos Humanos de Andalucía (2007) http://www.apdha.org
} 
for migrant identification. This status was denounced in a 2018 human rights report, ${ }^{7}$ that stated:

[I] t should be noted that there is no government agency dedicated to the identification of the corpses of people who have died on the boat while making the migratory journey, which represents a serious violation of rights, since, beyond the difficulties inherent in identification, the administration does not develop adequate mechanisms to carry it out.

When a deceased migrant reaches the Canary Islands, the Civil Guard must take fingerprints and photographs, and depending on where the body is found, whether it is sea or land, the Civil Guard or the Police take responsibility. The bodies are taken to the institutes of legal medicine and a judicial case is opened. All the information generated feeds a national blind database for unidentified cadavers that is managed by the Security State Secretariat pending from the Ministry of Interior. The investigating judge and the forensic doctor investigate the cause of death and identification. In the Canary Islands, there are two Legal Medicine Institutes, one in each of the Canary provinces, located in Tenerife and Gran Canaria, while in the rest of the islands there are dependencies for legal medicine. The Tenerife Institute ${ }^{8}$ was founded in 2002, and the registry of files has been standardised since 2009. The Legal Medicine Institute in Gran Canaria ${ }^{9}$ was created in 2007 and since then records show 28 DNA samples from unidentified people, of which 22 are from buried migrants.

In the Canary Islands, the International Committee of the Red Cross (ICRC) is one of the few active groups attempting to identify the interred deceased migrants. We had the opportunity to meet with the Transregional Forensic Coordinator Euroasia, Jose Pablo Baraybar, who is the person responsible for ICRC in West African and the Canary Islands, and with Benedicte L'Eplattenier, Transregional Adviser for Restoring Family Links and Missing Persons in relation to migration. The Deaths at the Borders of Southern Europe Database ${ }^{10}$ is the first collection of official, state-produced evidence on deceased migrants attempting to reach southern EU countries from the Balkans, the Middle East, and North and West Africa, and whose bodies were found in or brought to Europe. One of the biggest challenges in the personal identification of migrants is establishing their country of origin. The ICRC focuses on contextual events to track the possible provenance, using algorithms to predict the origin, based on the boat wreck information, survivors, and data from other countries (such as Italy). Jose Pablo and Benedicte explained that ICRC is currently updating the Deaths at the Borders of Southern Europe Database to 2019. This data is the most reliable source for Canary Islands data, recording 302 migrants buried in the Canary

\footnotetext{
${ }^{7}$ http://ddhhfronterasur.org/assets/frontera-sur.pdf

8 The meeting was with the Director Jesus Vega of Instituto de Medicina Legal de Santa Cruz.

9 The meeting was with the Director Eva Bajo Tobio of Instituto de Medicina Legal de Las Palmas.

${ }^{10}$ www.borderdeaths.org/
} 
Islands, of which 249 are unidentified. One of the challenges in identification is the match between the AM and PM data; in Europe the PM database is extensive, but in West African countries the data may not exist, and it is therefore not possible to confirm identity.

In an attempt to update and clarify the numbers and associated details of buried migrants in the Canary Islands, we made a formal request to the Interior Ministry, applying for the number of cases and type of information (but not individual data). The same information was also requested from the Canarian Government to access the information that exists in the Legal Medicine Institutes. No responses have been obtained, although both directors expressed their willingness to collaborate.

In Fuerteventura, we made a formal request, through Judge Dean, to access information on the MDVI cases. The judge informed us that the request must be made through the government (we have made an application, which to date has had no response). As there was no response from the courts, we decided to apply to the island's municipalities who administer the cemeteries. There are six municipalities on the island (Fuerteventura), of which four responded, with three providing data: six burials from a single boat in 1999, one burial from 2003, and one niche with 13 bodies from 2003 and 2004. For municipalities that did not answer or provide data, we counted the visible niches in the cemeteries marked as migrant burials; 68 niches were counted. This made a minimum total of 89 unidentified migrants in Fuerteventura (see table 2). The Deaths at the Borders database recorded 145 migrants, of which 126 are unidentified ( 82 men, 2 women, 46 sex unknown). These figures suggest that some burial niches may contain more than one deceased migrant and some deceased migrants are not recorded.

\section{Senegal}

Senegal is a country located in West Africa, surrounding The Gambia and bordered by Mauritania to the north, Mali to the east, Guinea to the southeast and GuineaBissau to the southwest. After Senegalese independence from France in 1960, migration continued, and new destinations emerged across the world. The main motivations for migration are poverty and the lack of a future for young people (more than half of the Senagalese population is under the age of 20). Migration is synonymous with prosperity and families with migrant relatives have money, they can build houses, create new businesses and provide stability to the family economy. In contrast, families with relatives who do not make it to a migrant destination leave a large hole in the family economy. The typical Senegalese migrant is a 19-30-year-old man, although in the last decade young women have also become migrants, as a means of independence and power (Ndione et al. 2018). 
It is not difficult to understand the thousands of Senegalese who embark for Europe via the Canary Islands. The peak of migration from Senegal to the Canary Islands was 2006, with more than 30,000 people arriving and more than 6,000 deaths in that year alone. After this peak, the wave of canoe arrivals declined due to new policies created by the governments of Spain, Morocco and Senegal, but although it seemed that this route had been abandoned, it has resurfaced as a popular route in recent years. In April 2020, 1,477 people arrived on the Canary Islands in 51 boats (Inmigracion Irregular 2020).

Senegal has adopted a new 'Plan for an Emerging Senegal in 2035' (PES) that forms the reference framework for the national economic and social policy over the mid- and long-term. To this end, the government has initiated actions designed to sustainably raise growth potential, as well as drive creativity and private initiative to satisfy people's aspiration for a better life. The government's three priorities are structural transformation of the economy, promotion of human capital and good governance. The Senegalese government does not currently have a migration policy and although there is government data relating to legal mobilisations inside and outside the African continent, there is no data relating to clandestine migrations.

Over the course of this project, we tried to arrange meetings and interviews with the government and the competent authorities; in some cases, they diverted us to different authorities and in other cases, never responded. In some of the interviews with researchers and associations, it was confirmed that the government is not interested in the identification of dead migrants. Laurent de Boeck, IOM deputy regional representative (The New Humanitarian 2006), stated 'There is little incentive to stop migration because it brings in more funds than development aid', and Ndione et al. (2018) stated 'There is no process of coordination of political relations between the migration and the national level of Senegal'. Since the Senegalese government has had a minimal interest in migration matters, there is no intention to account for the many people who have disappeared en route to Europe, let alone attempt to identify those migrants unlucky enough to be buried in Europe. This task and that of caring for family members has fallen to NGOs and organisations created by the local communities.

In Senegal, through the associations and the survivors, we observed community distrust with humanitarian assistance from Europe. In 2006, many migration associations were created, but the aid never arrived, and consequently people do not trust the NGOs and do not easily cooperate with international organisations. However, the families also do not trust the police or the government, due to fears of criminal charges, community shame and financial implications of repatriation. Therefore, in order to collect missing migrant information from families in Senegal, it is necessary to foster local liaison, to earn trust and create sustainable partnerships.

ICRC Senegal works with migrant families, and one of their aims is the creation of a national missing persons list. Although this might be a relatively easy task in 
European countries, in Senegal the reality is very different; families only report missing children or victims of kidnapping to the authorities, otherwise communities do not trust the authorities and turn to alternative networks to try and find the missing person. These informal networks include the local Iman or Marabou, who search for news through mosque or spiritual connections. Nicolas Mendy, RCS Project Manager of Families of Missing Migrants (FMD), stated:

It is important to establish a relationship of trust between community leaders and the families of missing migrants. To help them, you need compassion and not judgment. It is a double suffering of losing one's child and becoming stigmatized, isolated, sometimes banished within one's community. If someone loses their child and you blame him for being responsible, you put him down. ${ }^{11}$

The ICRC has been developing a AM-PM database adjusted to the reality of the migrants. The ICRC branch, Restoring Family Links (RFL), has also developed the project 'Trace the Faces', where families can try to find their missing family members online, ${ }^{12}$ but this project is more focused on finding living migrants rather than collecting data for identification of bodies and, when the families of migrants who go missing in Senegal get in contact with the ICRC, psychosocial support is offered. ${ }^{13}$

In addition to ICRC Senegal, IOM is creating realistic databases of the missing migrants in Senegal and these data are available online via the Missing Migrants Project. ${ }^{14}$ The IOM also wants to create a register of Senagelese associations related to migration; in Dakar almost all districts have such associations, but there is not an official list and they are not all supported by the government. With this data the IOM provides a useful tool for missing identification.

The local organisations who are currently collecting missing persons information directly from the families cannot share this data due to data protection regulations.

It is worth noting that clandestine migration from Senegal will not cease until those who remain have options for their future.

\section{Use of facial identification and social media images}

In West and Northern Africa, mobile phone coverage has been expanding in parallel to increased African migration to Europe, and mobile phones facilitate and shape migration patterns (Schaub 2012). Historically, mobile phone penetration as a

\footnotetext{
${ }^{11} \mathrm{https} / / /$ reliefweb.int/report/senegal/s-n-gal-pour-les-familles-de-migrants-port-s-disparus-le-soutiende-leur-communaut

12 https://familylinks.icrc.org/euro

13 www.icrc.org/en/document/senegal-new-hope-families-missing-migrants

${ }^{14}$ Personal communication with Jusselme Damien and Wilfried Coly from OIM Senegal, 11 August 2019.
} 
percentage of population in Senegal increased from 0.001 per cent in 1994 to 99.9 per cent in $2015 .{ }^{15}$ GSMA (2017) states that depending on the context, refugees may be highly connected, with 90 per cent of refugees in urban areas covered by $3 \mathrm{G}$ networks. There is evidence that mobile phones are a critical tool in migrant organisation, transportation and transnational communication (Zijlstra \& Liempt 2017), and specifically for Senegalese migrants to the Canary Islands and Spain (Nyamnjoh 2013). It is still the case that people in wealthier countries have higher rates of internet use and smartphone ownership (Poushter et al. 2018). However, among people who use the internet, those in developing countries often turn out to be more likely than their counterparts in advanced economies to network via platforms like Facebook and Twitter (Poushter et al. 2018). Facebook states that 65 per cent of Facebook users are under 35 years (the likely migrant demographic) and 96 per cent of active users accessed the social media platform via mobile devices. ${ }^{16}$ In 2013 (just before the peak of migrant deaths on Mediterranean crossings), Facebook revealed ${ }^{17}$ that its users had uploaded more than 250 billion images and uploaded 350 million new images each day. To put that into perspective, that would mean that each of Facebook's 1.15 billion users uploaded an average of 217 images apiece. In 2016, Google announced ${ }^{18}$ that more than 200 million people uploaded images to the application each month, of which 24 billion were selfies.

Selfies taken on mobile phones can be a useful source of material for identification. Olivieri and colleagues (2018) recommend the use of face data for the identification of dead migrants. Their study found that photographs and videos (social/candid scenarios) were frequently available from families as AM data along with recent images of the missing person retrieved from Facebook or other social media platforms. The authors also called for the use of $3 \mathrm{D}$ face capture at post-mortem examination as a valuable tool for later comparison with AM images.

Research has shown that surface details on the face, such as moles, creases, wrinkles, hair pattern and scars can be utilised for identification (Pierrard \& Vetter 2007; Jain \& Park 2009; Ramesha et al. 2010; Jain et al. 2012) and the morphological assessment of facial features is recommended by the Facial Identification Scientific Working Group (FISWG) for facial image comparison (FISWG 2020). Taphonomic literature demonstrates that faces change significantly with post-mortem processes including putrefaction, bloating, destruction and skeletonisation and research using 3D scan

\footnotetext{
15 www.helgilibrary.com/indicators/mobile-phone-penetration-as-of-population/senegal/\#: :text $=$ Mobile $\% 20$ phone $\% 20$ penetration $\% 20$ as $\% 20$ a, than $\% 20$ in $\% 20$ the $\% 20$ previous $\% 20$ year

${ }^{16}$ www.omnicoreagency.com/facebook-statistics/

$17 \mathrm{https}: / /$ mashable.com/2013/09/16/facebook-photo-uploads/?europe=true

${ }^{18} \mathrm{https} / / /$ blog.google/products/photos/google-photos-one-year-200-million/
} 
and photographic records has demonstrated early post-mortem changes to the face (Wilkinson \& Tillotson 2012), including dehydration/shrinkage at the orifices (orbit, mouth and nose) in most (60 per cent) cadavers along with swelling at the periphery of the face in some (30 per cent) cadavers. Additional research using embalmed cadavers (Hadi and Wilkinson 2014) identified 20 facial creases that were resilient with bloating, suggesting that facial creases can be utilised for post-mortem identification. The use of AM and PM facial images for identification has been further evaluated (Caplova et al. 2017) using morphological comparisons and expert or student observers. The authors found a median recognition accuracy of up to 100 per cent was achieved across all observers depending on the image setup, indicating that comparison of facial images of unfamiliar dead and living persons may be used as a preliminary recognition method by a third person in the absence of other identifying markers.

\section{Summary}

The resulting recommended content for an online MDVI database has been an important outcome of this research.

In the Canary Islands, there has been no attempt to identify deceased migrants, although the local island judge has access to all cases and can approve the official identification for each migrant victim. To access any information about migrants and/ or exhumation, a permit is required from the Secretary of the Ministry of the Interior and local governments, but this is a time-consuming, bureaucratic process making access exceptionally difficult. The recently established Medicolegal Institutes of the Canary Islands do now record the latest cases. There is no specific database for the identification of migrants in the Canary Islands and the most reliable database is from the ICRC border deaths (from 1990 to 2019), but this is not yet publicly available.

There are 249 unidentified migrant bodies in the Canary Islands, of which 166 are men, 7 women and 76 unknown sex. The main cause of death is 69.7 per cent drowning, 14.5 per cent dehydration, 9.2 per cent hypothermia and 6.6 per cent other causes. The published data for the island of Fuerteventura are 82 men, 2 women and 42 unknown sex, and 84.8 per cent of the cause of death is drowning, 12 per cent hypothermia and 3.2 per cent other causes. To compare this published information with local records, we used the island of Fuerteventura as a pilot. Information was requested from the municipal governments and was completed by counting marked niches in cemeteries. In total we counted 88 unidentified migrants, which differs from the published database by -38 people. However, we know that sometimes a single niche is utilised for several bodies, so there is a possibility that they are within the counted niches. 
In Senegal, there is community distrust with humanitarian assistance from Europe, due to past disappointments, alongside distrust of the police or the government, due to fear, shame and financial concerns. Therefore, it is critical for future identification efforts to establish local liaison and sustainable partnerships, and to iron out data protection challenges associated with the necessary sharing of migrant/missing person data.

3D face capture and facial photography during PM examination provides a valuable resource for later comparison with AM images sourced from social media posts and selfies taken on mobile phones. Surface details on the face, such as moles, creases, wrinkles, hair pattern and scars are resilient features, even through early post-mortem changes, and can be utilised for morphological assessment and identification.

\section{Acknowledgements}

The authors would like to thank our collaborators at the University of Milan (Prof Cristina Cattaneo and Prof Danilo De Angelis) and the University La Laguna, Tenerife (Prof Matilde Arany de la Rosa and Prof Emilio Gonzalez-Reimers) for valuable insights, experience and research contribution. This project was supported by the British Academy Knowledge Frontiers Fund.

\section{References}

Adepoju, A. (2008), Migration in Sub-Saharan Africa (Uppsala, Nordiska Afrikainstitutet).

Ampuero Villagran, O. (2018), Identifying Migrant Bodies in the Mediterranean, Policy Report No. 05/02 (Barcelona, United Nations University Institute on Globalization, Culture and Mobility (UNU-GCM)).

Andersson, R. (2014), Illegality, Inc.: Clandestine Migration and the Business of Bordering Europe (Oakland, University of California Press).

Batalova, A., Shymonyak, A. \& Mittelstadt, M. (2018), Immigration Data Matters. Migration Policy Institute Population Reference Bureau, March 2018.

Ben Attia, F., Brian, T., Heiermann, A.C., Grant, S., Jarvis, C., Kovras, I. \& Shaiah, A. (2016). 'Like a part of a puzzle which is missing': The impact on families of a relative missing in migration across the Mediterranean.

Ben Attia, F., Brian, T., Heiermann, A.C., Grant, S., Jarvis, C., Kovras, I., Laczko, F., Mirto, G., Polychroni, K., Robins, S., Singleton, A. \& Shaiah, A. (2017), Missing Migrants in the Mediterranean: Addressing the Humanitarian Crisis. Summary report.

BOPC (2011), Plan Canario Inmigración 2002-2004; Gobierno de Canarias. http://www.datosdelanzarote.com/uploads/doc/20060422140143658PLANCANARIOPARALAINMIGRACION.pdf

Brian, T. \& Laczko, F. (2016), Fatal Journeys Volume 2. Identification and Tracing of Dead and Missing Migrants (Geneva, International Organization for Migration Global Migration Data Analysis Centre).

Brough, A.L., Rutty, G.N., Black, S. \& Morgan, B. (2012), 'Postmortem Computed Tomography and 3D Imaging: Anthropological Applications for Juvenile Remains', Journal of Forensic Science, Medicine \& Pathology, 8(3): 270-9. 


\section{The current status of Migrant Disaster Victim Identification in the Canary Islands 133}

Caplova, Z., Obertova, Z., Gibelli, D.M., Mazzarelli, D., Fracasso, T., Vanezis, P., Sforza, C. \& Cattaneo, C. (2017), 'The Reliability of Facial Recognition of Deceased Persons on Photographs', Journal of Forensic Sciences, 62(5): 1286-91. https://doi.org/10.1111/1556-4029.13396

Cattaneo, C., Porta, D., De Angelis, D., Gibelli, D., Poppa, P. \& Grandi, M. (2010), 'Unidentified Bodies and Human Remains: An Italian Glimpse through a European Problem', Forensic Science International, 195(1): 167-e1.

Cattaneo, C., Binz, M.T., Penados, L., Prieto, J., Finegan, O. \& Grandi, M. (2015), 'The Forgotten Tragedy of the Unidentified Dead in the Mediterranean', Forensic Science International, 250: e1-e2.

Cuttitta, P. (2020), 'Preface: The Increasing Focus on Border Deaths'. In P. Cuttitta \& T. Last (eds) Border Deaths: Causes, Dynamics and Consequences of Migration-related Mortality (pp. 9-20). (Amsterdam, Amsterdam University Press) https://doi.org/10.2307/j.ctvt1sgz6.4.

De Haas, H. (2006), Trans-Saharan migration to North Africa and the EU: Historical Roots and Current Trends (International Migration Institute, University of Oxford, UK).

Dudek, C.M. \& Pestano, C. (2019), 'Canarios En Una Mina: La Crisis Migratoria de Los Cayucos y La Europeización de La Política Migratoria’, Revista Española de Ciencia Política, 49: 85-106. https://doi.org/10.21308/recp.49.04

Ellingham, S.T.D., Perich, P. \& Tidball-Binz, M. (2017). 'The fate of human remains in a maritime context and feasibility for forensic humanitarian action to assist in their recovery and identification', Forensic science international, 279, 229-234.

Espuche, B., Marco, M. Á., Lara, R., Rodier, C., Miraglia, F. \& Callus, A. (2007), Derechos Humanos en la frontera sur 2007. Asociación Pro-Derechos Humanos de Andalucía. https://www.apdha.org/ webanterior/media/informeinmigra07.pdf

European Commissioner for Human Rights (2007), The Human Rights of Irregular Migrants in Europe. https://rm.coe.int/ref/CommDH/IssuePaper(2007)1

Fall, P.D. (2007), 'Ndaraw, Sekka, Sidi Bara, Yéri et les autres. Enquêtes sur le mbëkk dans la banlieue dakaroise', Communication au Séminaire de la Commission scientifique de l'IFAN Ch. A. Diop sur Barça ou Barsaq: quelles lectures des sciences sociales sur l'actualité des migrations internationales? (Dakar, Senegal). www.learningace.com/doc/2518213/e65de58e6afc9e04a0f1ada9919bd5d0/ ndaraw-sekka-sidi-bara-yeri

FISWG (2020), Standard Practice/Guide for Image Processing to Improve Automated Facial Recognition Search Performance. https://www.fiswg.org/fiswg_image_proc_to_improve_fr_search_ v2.0_2020.07.17.pdff

Grant, S. (2011), 'Recording and Identifying European Frontier Deaths', European Journal of Migration and Law, 13(2): 135-56.

GMDAC (2016), Missing migrants in the Mediterranean: Addressing the humanitarian crisis. Summary report.

GSMA (2017), The Importance of Mobile for Refugees: A Landscape of New Services and Approaches. www.gsma.com/mobilefordevelopment/wp-content/uploads/2017/02/The-Importance-of-mobilefor-refugees_a-landscape-of-new-services-and-approaches.pdf

Guillén, M. (2011), 'Análisis de la migración irregular áfrica-canarias’, Miradas en movimiento, v: 4-26.

Hadi, H. \& Wilkinson, C.M. (2014), 'The Post-mortem Resilience of Facial Creases and the Possibility for Use in Identification of the Dead', Forensic Science International, 237: 149.e1-149.e7. https:// doi.org/10.1016/j.forsciint.2013.12.014

International Organization for Migration (2013), World Migration Report 2013: Migrant Well-being and Development. Volume 7. http://publications.iom.int/system/files/pdf/wmr2013_en.pdf

International Organization for Migration (2018), Central Mediterranean Route Thematic Report Series-Analysis of Best Practices in the Identification of Missing Migrants: Implications for the Central Mediterranean. Issue No. 2. https://publications.iom.int/books/ central-mediterranean-route-thematic-report-series-analysis-best-practices-identification 
Jain, A.K. \& Park, U. (2009, November), 'Facial Marks: Soft Biometric for Face Recognition', in 2009 16th IEEE International Conference on Image Processing (ICIP), 37-40.

Jain, A.K., Klare, B. \& Park, U. (2012), 'Face Matching and Retrieval in Forensics Applications', IEEE multimedia, 19(1): 20.

Kovras, I. \& Robins, S. (2016), 'Death as the border: Managing missing migrants and unidentified bodies at the EU's Mediterranean frontier', Political Geography, 55, 40-49.

Kemp, W. (2016) Learning from the Canaries: Lessons from the 'Cayucos' Crisis (New York, International Peace Institute). https://ssrn.com/abstract=2893320

Latza Nadeau, B. (2017), 'Giving Dead Migrants a Name', Scientific American, 9 August. www.scientificamerican.com/article/giving-dead-migrants-a-name/

Last, T., Mirto, G., Ulusoy, O., Urquijo, I., Harte, J., Bami, N. ... \& Spijkerboer, T. (2016), 'Deaths at the Borders Database: Evidence of Deceased Migrants' Bodies Found Along the Southern External Borders of the European Union', Journal of Ethnic and Migration Studies, 43(5): 693-712.

Maher, S.C. (2015), Barça Ou Barzakh: The Social Elsewhere of Failed Clandestine Migration out of Senegal. https://digital.lib.washington.edu:443/,/handle/1773/35119

Mbaye, L.M. (2014), “"Barcelona or Die”: Understanding Illegal Migration from Senegal', IZA Journal of Migration, 3: 21. https://doi.org/10.1186/s40176-014-0021-8

Ministry of the Interior Government of Spain (2020). Biweekly Report on Irregular Immigration, http:// www.interior.gob.es/documents/10180/11389243/informe_quincenal_acumulado_01-01_al_3103-2020.pdf/d4bb8c26-5f5c-4863-8d85-6ac7eae8cf08

Ndione, L., Decrop, A. \& Rémy, E. (2018), 'Migrants Going Back Homeland for Holidays: Rituals and Practices of Senegalese Migrants in France', Annals of Tourism Research, 70: 25-38.

Nyamnjoh, H. (2013), 'Information and Communication Technology and its Impact on Transnational Migration: The Case of Senegalese Boat Migrants', Side@Ways, 159.

Olivieri, L., Mazzarelli, D., Bertoglio, B., De Angelis, D., Previderè, C., Grignani, P. ... \& Cattaneo, C. (2018), 'Challenges in the identification of dead migrants in the Mediterranean: the case study of the Lampedusa shipwreck of October 3rd 2013', Forensic science international, 285, 121-128.

Pierrard, J.S. \& Vetter, T. (2007), 'Skin Detail Analysis for Face Recognition', in 2007 (June) IEEE Conference on Computer Vision and Pattern Recognition (IEEE), 1-8.

Poushter, J., Bishop, C. \& Chwe, H. (2018), 'Social Media Use Continues to Rise in Developing Countries but Plateaus across Developed Ones', Pew Research Center, 22: 2-19.

Ramesha, K., Raja, K.B., Venugopal, K.R. \& Patnaik, L.M. (2010), 'Template Based Mole Detection for Face Recognition', International Journal of Computer Theory and Engineering, 2(5): 798-820.

Rodríguez Díaz, R. \& Montes, N.M. (2008), 'Opinión Pública y frames: La crisis de los cayucos', Revista Latina de Comunicación Social. https://doi.org/10.4185/RLCS-63-2008-772-341-347

Schaub, M.L. (2012), 'Lines across the Desert: Mobile Phone Use and Mobility in the Context of Trans-Saharan Migration', Information Technology for Development, 18(2): 126-44. DOI: 10.1080/02681102.2011.604082

Singleton, A., Laczko, F. \& Black, J. (2017), 'Measuring Unsafe Migration: The Challenge of Collecting Accurate Data on Migrant Fatalities', Migration Policy Practice, 7(2): 4-9. https://publications. iom.int/system/files/pdf/migration_policy_practice_journal_30.pdf

The New Humanitarian (2006), 'Setting sights across the sea' 31 october 2006, https://www.thenewhumanitarian.org/news/2006/10/31/setting-sights-across-sea

Triandafyllidou, A. \& McAuliffe, M.L. (eds) (2018), Migrant Smuggling Data and Research: A global review of the emerging evidence base, Volume 2 (Geneva, International Organisation for Migration).

Wilkinson, C.M. (2010), 'Facial Reconstruction: Anatomical Art or Artistic Anatomy?', Journal of Anatomy, 216(2): 235-50.

Wilkinson, C.M. \& Tillotson, A. (2012), 'Post-mortem Prediction of Facial Appearance', in C.M. Wilkinson and C. Rynn (eds), Craniofacial Identification (Cambridge, Cambridge University Press), 166-83. 
Zijlstra, J. \& Liempt, I.V. (2017), 'Smart (Phone) Travelling: Understanding the Use and Impact of Mobile Technology on Irregular Migration Journeys', International Journal of Migration and Border Studies, 3(2-3): 174-91.

To cite the article: Caroline Wilkinson and Maria Castaneyra-Ruiz (2021), 'The current status of Migrant Disaster Victim Identification in the Canary Islands', Journal of the British Academy, 9(s8): 115-35.

DOI https://doi.org/10.5871/jba/009s8.115

Journal of the British Academy (ISSN 2052-7217) is published by The British Academy, 10-11 Carlton House Terrace, London, SW1Y 5AH

www.thebritishacademy.ac.uk 